\title{
Microbial Lipopeptide-Producing Strains and Their Metabolic Roles under Anaerobic Conditions
}

\author{
Jia-Yi Li ${ }^{1}$, Lu Wang ${ }^{2}$, Yi-Fan Liu ${ }^{1,3}{ }^{\mathbb{D}}$, Lei Zhou ${ }^{1,3}$, Hong-Ze Gang ${ }^{1,3}$, Jin-Feng Liu ${ }^{1,3}$, Shi-Zhong Yang ${ }^{1,3, *}$ \\ and Bo-Zhong Mu ${ }^{1,3}$ (D) \\ 1 State Key Laboratory of Bioreactor Engineering, School of Chemistry and Molecular Engineering, \\ East China University of Science and Technology, Shanghai 200237, China; \\ Y30190306@mail.ecust.edu.cn (J.-Y.L.); liuyifan@ecust.edu.cn (Y.-F.L.); leizhou@ecust.edu.cn (L.Z.); \\ ganghz@ecust.edu.cn (H.-Z.G.); lj@@ecust.edu.cn (J.-F.L.); bzmu@ecust.edu.cn (B.-Z.M.) \\ 2 State Key Laboratory of Enhanced Oil Recovery, Research Institute of Petroleum Exploration and \\ Development, CNPN, Beijing 100083, China; luwangmoon@petrochina.com.cn \\ 3 Engineering Research Center of MEOR, East China University of Science and Technology, \\ Shanghai 200237, China \\ * Correspondence: meor@ecust.edu.cn; Tel.: +86-21-64252063
}

check for updates

Citation: Li, J.-Y.; Wang, L.; Liu, Y.-F.; Zhou, L.; Gang, H.-Z.; Liu, J.-F.; Yang, S.-Z.; Mu, B.-Z. Microbial

Lipopeptide-Producing Strains and

Their Metabolic Roles under Anaerobic Conditions.

Microorganisms 2021, 9, 2030.

https://doi.org/10.3390/

microorganisms 9102030

Academic Editor: James Chong

Received: 23 July 2021

Accepted: 10 September 2021

Published: 25 September 2021

Publisher's Note: MDPI stays neutral with regard to jurisdictional claims in published maps and institutional affiliations.

Copyright: (c) 2021 by the authors. Licensee MDPI, Basel, Switzerland. This article is an open access article distributed under the terms and conditions of the Creative Commons Attribution (CC BY) license (https:/ / creativecommons.org/licenses/by/ $4.0 /)$.

\begin{abstract}
The lipopeptide produced by microorganisms is one of the representative biosurfactants and is characterized as a series of structural analogues of different families. Thirty-four families covering about 300 lipopeptide compounds have been reported in the last decades, and most of the reported lipopeptides produced by microorganisms were under aerobic conditions. The lipopeptideproducing strains under anaerobic conditions have attracted much attention from both the academic and industrial communities, due to the needs and the challenge of their applications in anaerobic environments, such as in oil reservoirs and in microbial enhanced oil recovery (MEOR). In this review, the fifty-eight reported bacterial strains, mostly isolated from oil reservoirs and dominated by the species Bacillus subtilis, producing lipopeptide biosurfactants, and the species Pseudomonas aeruginosa, producing glycolipid biosurfactants under anaerobic conditions were summarized. The metabolic pathway and the non-ribosomal peptide synthetases (NRPSs) of the strain Bacillus subtilis under anaerobic conditions were analyzed, which is expected to better understand the key mechanisms of the growth and production of lipopeptide biosurfactants of such kind of bacteria under anaerobic conditions, and to expand the industrial application of anaerobic biosurfactant-producing bacteria.
\end{abstract}

Keywords: biosurfactant; anaerobic bacteria; nitrate respiration; non-ribosomal peptide synthetase (NRPSs)

\section{Introduction}

Biosurfactants are a group of microbial secondary metabolites with strong surface/ interfacial activity mainly produced by bacteria, yeasts, and fungi [1], and a kind of amphiphilic compounds with a wide structural variety including lipopeptide, glycolipid, phospholipid, polysaccharide-protein complexes, fatty acids, or natural lipids, etc. [2]. The microbial lipopeptide is one of the representative biosurfactants and is characterized as a series of structural analogues of different families. Thirty-four families covering about 300 lipopeptide compounds have been reported in the last decades, and among those families the surfactin, iturin, fengycin, and lichenysin are the most frequently reported ones. Microbial lipopeptides have been widely studied for their diverse biotechnological applications and have served as emulsifiers and stabilizers in food industry [3], formulations in cosmetic industry [4], oil displacement agent in microbial enhanced oil recovery (MEOR) [5], biocontrol agent in agriculture, and biodegradation and bioremediation in environmental protection system [6]. It has been proved that Bacillus [7], Pseudomonas [8], cyanobacteria [9], actinomycetes [10,11], and fungi [12] can produce lipopeptide biosurfactants. The families of iturin [13] and fengycin [14] were discovered in 1949 and 1986, respectively. 
Surfactin was first found in the culture medium of Bacillus subtilis in 1968, and it is a cyclic (polar) heptapeptide attached to $a \beta$-OH (lactone) fatty acid chain (11 to 16 carbons) [15-18]. Different modifications in the chiral sequence of amino acids in the peptide chain can occur; amino acids of the aliphatic group, Val, Leu, and Ile in positions 2nd, 4th, and 7th were already observed. Known for the exceptional emulsion and foamability, surfactin can reduce water surface tension from 72 to $27 \mathrm{mN} / \mathrm{m}$ at $\approx 10 \mathrm{mg} / \mathrm{L}[19,20]$. In addition to the powerful surfactant properties, surfactin showed broad biological activities such as hemolytic activities, modification of the performance of enzymes, and interaction with membranes.

Lipopeptide-producing bacteria have been extensively reported under aerobic conditions. Only a few bacteria have been identified as being able to produce lipopeptides in the absence of oxygen. However, a large number of environments inherited oxygen free conditions, such as deep sea and underground oil reservoirs, and the application of anaerobic lipopeptide-producing bacteria in industries is still a challenge. This review presented a summary on the fifty-eight reported bacterial strains that can produce biosurfactants under anaerobic conditions. The metabolic pathway and the non-ribosomal peptide synthetases (NRPSs) of the strain Bacillus subtilis under anaerobic conditions were analyzed, which is expected to lead to better understanding of the key mechanisms of the growth and production of lipopeptide biosurfactants of such kind of bacteria under oxygen-limiting conditions, and to expand the biotechnological and industrial applications of anaerobic lipopeptide-producing bacteria.

\section{Lipopeptide-Producing Strains under Anaerobic Conditions}

According to their tolerance to oxygen, the lipopeptide-producing microorganisms can be roughly divided into five categories: obligate aerobes, microaerophies, facultative anaerobes, aerotolerant anaerobes, and obligate anaerobes [21]. Most of the reported anaerobic microorganisms have been bacteria and archaea until now, as well as a small number of actinomycetes, mycoplasma, and fungi [22,23]. Since 1980, Cooper et al. discovered that Clostridium pasteurianum produced extracellular neutral lipopeptide surfactant under anaerobic conditions, which could reduce the surface tension of deionized water from $72 \mathrm{mN} / \mathrm{m}$ to $55 \mathrm{mN} / \mathrm{m}$ [24]. Up to now, there have been about thirty-six strains reported that can produce lipopeptide biosurfactant under anaerobic conditions, mainly isolated from oil reservoirs and oil contaminated soil samples, and dominated by the genera Bacillus, Pseudomonas, and Yeasts. There were also reports from lake sediments and hot spring samples. Among them, the lipopeptide surfactant produced by Bacillus mojavensis GMTB-C1-2 screened from submarine oil reservoirs showed a good surface activity under anaerobic conditions, which could reduce the surface tension of deionized water from $72 \mathrm{mN} / \mathrm{m}$ to $27 \mathrm{mN} / \mathrm{m}$ (Ghojavand et al., 2011) [25]. Bacillus licheniformis WJ-2, which was isolated from in Daqing Oilfield, China, in 2012, showed the best lipopeptide yield of $1.69 \mathrm{~g} / \mathrm{L}$ under anaerobic conditions [26]. The information of lipopeptide-producing strains (Bacillus) is summarized in Table 1.

In addition to Bacillus, a few of the lipopeptides-producing bacteria belonging to the Pseudomonas, Pallidobacterium, Rhodobacteria, and Piperacilla were also reported. In 2012, Geobacillus pallidus H9 was isolated from Daqing Oilfield, China, and the yield of macromolecular polysaccharide protein complex was up to $2.8 \mathrm{~g} / \mathrm{L}$ under anaerobic conditions at $65{ }^{\circ} \mathrm{C}$ [27]. In addition, it has been reported that Anaerophaga thermohalophila Fru22T (Oilfield, Hannover, Germany) [28], Rhodococcus ruber Z25 (Daqing Oilfield, Heilongjiang, China) [29], Tepidibacter mesophilus B1T (Karamay Oilfield, Xinjiang, China) [30], and Luteimonas huabeiensis HB-2 (Baogeli Oilfield, Xinjiang, China) [31] can produce lipopeptides under anaerobic conditions. The earliest mention of production of biosurfactants under anaerobic conditions was published in 1955 [32], where another twenty-two strains of anaerobic wild bacteria producing glycolipid biosurfactants or other biosurfactants were reported. The information around other biosurfactant-producing strains is summarized in Table 2. 
Table 1. Information of lipopeptide-producing strains (Bacillus) under anaerobic conditions.

\begin{tabular}{|c|c|c|c|c|}
\hline Year & Source & Strain & Biosurfactant & References \\
\hline 1980 & Unknown & Clostridium pasteurianum & Neutral lipid & [24] \\
\hline 1985 & Oklahoma oilfield, US & Bacillus mojavensis JF-2 & Lipopeptide & [33] \\
\hline 1995 & Oilfield, North Germany & Bacillus licheniformis BAS50 & Lichenysin A & [34] \\
\hline 1997 & Oilfield, North Germany & Bacillus licheniformis BNP29 & Lipopeptide & [35] \\
\hline 1997 & Oilfield, North Germany & Bacillus licheniformis BNP36 & Lipopeptide & [35] \\
\hline 1997 & Oilfield, North Germany & Bacillus licheniformis Mep132 & Lipopeptide & [35] \\
\hline 1997 & Oilfield, Russian & Bacillus subtilis C9 & Surfactin & [36] \\
\hline 1999 & Marine sediments & Bacillus subtilis ATCC 21332 & Lipopeptide & [37] \\
\hline 2000 & $\begin{array}{c}\text { Noyabrskyi oilfield, } \\
\text { Russian }\end{array}$ & Bacillus subtilis BS2202 & Lipopeptide & [38] \\
\hline 2001 & Water buffalo & Bacillus licheniformis 26 L-10 & Lipopeptide & [39] \\
\hline 2004 & Oklahoma oilfield, US & Bacillus subtilis ATCC 12332 & Lipopeptide & {$[40]$} \\
\hline 2007 & Sahara desert, Tunisia & Bacillus subtilis RS-1 & Lipopeptide & [41] \\
\hline 2007 & Oilfield, Iran & Bacillus subtilis PTCC 1365 & Lipopeptide & [42] \\
\hline 2008 & Unknown & Bacillus subtilis ATCC6633 & $\begin{array}{l}\text { Mycosubtilin, } \\
\text { surfactin }\end{array}$ & [43] \\
\hline 2009 & Russia & Bacillus licheniformis VKM B-511 & Licheniformin A & [44] \\
\hline 2009 & Hot springs, US & Bacillus licheniformis TT33 & Lipopeptide & [45] \\
\hline 2011 & Oilfield, Iran & Bacillus mojavensis GMTB-C1-2 & Lipopeptide & [25] \\
\hline 2011 & Oilfield, US & Bacillus cereus ATCC14579 & Lipopeptide & [46] \\
\hline 2012 & Oilfield, Brazil & Bacillus subtilis 309 & Sufactin & [47] \\
\hline 2012 & Oilfield, Brazil & Bacillus subtilis 191 & Lipopeptide & [47] \\
\hline 2012 & Oilfield, Brazil & Bacillus subtilis 311 & Sufactin & [47] \\
\hline 2012 & Oilfield, Brazil & Bacillus subtilis 552 & Lipopeptide & [47] \\
\hline 2012 & Oilfield, Brazil & Bacillus subtilis 573 & Sufactin & [47] \\
\hline 2012 & Daqing oilfield, China & Bacillus licheniformis WJ-2 & $\begin{array}{l}\text { Glycosides, } \\
\text { Lipopeptides }\end{array}$ & [26] \\
\hline 2012 & Soil from Ituri, Congo & Bacillus amyloliquefaciens S499 & $\begin{array}{l}\text { Surfatin, Iturin } \\
\text { and Fengycin }\end{array}$ & [48] \\
\hline 2015 & Oilfield, Germany & Bacillus subtilis DSM 10T & Lipopeptide & [49] \\
\hline 2017 & Daqing oilfield, China & Bacillus licheniformis DQ4 & Lipopeptide & [50] \\
\hline 2017 & Xinjiang oilfield, China & Bacillus amyloliquefaciens 702 & $\begin{array}{l}\text { Glycosides, } \\
\text { Lipopeptides }\end{array}$ & [51] \\
\hline 2018 & Shengli oilfield, China & Bacillus licheniformis & $\begin{array}{l}\text { Glycosides, } \\
\text { Lipopeptides }\end{array}$ & [52] \\
\hline 2019 & Shengli oilfield, China & Bacillus tequilensis & $\begin{array}{l}\text { Glycosides, } \\
\text { Lipopeptides }\end{array}$ & [53] \\
\hline 2021 & Xinjiang oilfield, China & Bacillus subtilis AnPL-1 & Sufactin & [54] \\
\hline
\end{tabular}

These biosurfactant-producing bacteria mostly choose nitrate or sulfate as the alternative electron acceptor under oxygen deprivation. Generally, these studies presented higher lipopeptide yields under oxygen-rich conditions than in oxygen limiting conditions. It is speculated that their production is reduced under anaerobic conditions, considering that the available energy is preferentially used in primary metabolic pathways rather than secondary metabolic pathways. The slow growth of bacteria in oxygen-limiting conditions can also reduce the growth-dependent products of lipopeptide. On the other hand, the difference of intercell microenvironments under aerobic and anerobic conditions may affect the substrate preferences change due to the redox potential of the biochemical reactions and the usage of different electron acceptors [53]. This may lead to changes in the metabolic pathways involved in the production of lipopeptide. When bacteria encounter the transformation from oxygen enriched environment to hypoxia environment, it is of great significance for bacteria to make a reasonable stress transformation for their growth and metabolism. However, there are few reports on the differences of biosurfactant secondary metabolism of these bacteria under aerobic and anaerobic conditions. 
Table 2. Information of biosurfactant-producing strains under anaerobic conditions.

\begin{tabular}{|c|c|c|c|c|}
\hline Year & Source & Strain & Biosurfactant & References \\
\hline 1955 & Ain-ez-Zania lake, Lybia & $\begin{array}{l}\text { Desulfovibrio desulfuricans sp. } \\
\text { DSM } 1926\end{array}$ & Unidentified & [32] \\
\hline 1991 & Hot springs, USA & $\begin{array}{c}\text { Thermoanaerobacter } \\
\text { pseudethanolicus ATCC } 33233\end{array}$ & Unidentified & {$[55]$} \\
\hline 2000 & $\begin{array}{l}\text { Petroleum contaminated } \\
\text { soil }\end{array}$ & Pseudomonas sp.BS2201 & Unidentified & {$[56]$} \\
\hline 2000 & $\begin{array}{l}\text { Petroleum contaminated } \\
\text { soil }\end{array}$ & Pseudomonas sp. BS2203 & Unidentified & [56] \\
\hline 2000 & Oilfield, India & $\begin{array}{c}\text { Pseudomonas aeruginosa ATCC } \\
10145\end{array}$ & Rhamnolipid & [57] \\
\hline 2002 & Oilfield, Germany & Isolate Glc2 & Unidentified & [58] \\
\hline 2007 & Antarctic soil & Pantoa A-13 & Rhamnolipid & [59] \\
\hline 2007 & Hospital Wastewater & Pseudomonas aeruginosa PAO1 & Rhamnolipid & [60] \\
\hline 2008 & Shengli oilfield, China & Pseudomonas aeruginosa SH6 & Rhamnolipid & [61] \\
\hline 2010 & Municipal Sewage Sludge & $\begin{array}{c}\text { Pseudomonas aeruginosa } \\
\text { ANBIOSURF-1 }\end{array}$ & Rhamnolipid & [62] \\
\hline 2012 & Oilfield; Veracruz, Mexico & Thermoanaerobacter sp. & Unidentified & [63] \\
\hline 2012 & Menggulin oilfield, China & Pseudomonas aeruginosa WJ-1 & Rhamnolipid & [64] \\
\hline 2013 & Soil samples, Iowa, USA & Pseudomonas aeruginosa E03-40 & Rhamnolipid & [65] \\
\hline 2013 & Oil contaminated soil, Iran & Enterobacter cloacae & Unidentified & {$[66]$} \\
\hline 2014 & Gachsaran oilfield, Iran & $\begin{array}{c}\text { Bacillus stearothermophilus } \\
\text { SUCPM\#14 }\end{array}$ & Unidentified & [67] \\
\hline 2015 & Xinjiang oilfield, China & Pseudomonas aeruginosa SG & Rhamnolipid & {$[68-70]$} \\
\hline 2017 & Xinjiang oilfield, China & Pseudomonas aeruginosa 709 & Rhamnolipid & [60] \\
\hline 2018 & Daqing oilfield, China & Pseudomonas aeruginosa DQ3 & Rhamnolipid & {$[71]$} \\
\hline 2018 & Daqing oilfield, China & Pseudomonas aeruginosa DQ1 & Rhamnolipid & {$[71]$} \\
\hline 2018 & Daqing oilfield, China & Pseudomonas aeruginosa DQ5 & Rhamnolipid & [71] \\
\hline 2018 & Daqing oilfield, China & Pseudomonas aeruginosa DQ6 & Rhamnolipid & [71] \\
\hline 2020 & Dagang oilfield, China & Bacillus licheniformis DM-1 & Exopolysaccharide & [72] \\
\hline
\end{tabular}

\section{The Mechanism of Anaerobic Growth of Bacillus subtilis}

According to the respiration mode of microorganisms, it can be divided into aerobic respiration, anaerobic respiration, and fermentation [73]. During aerobic respiration, electron transfer phosphorylation uses oxygen as an electron acceptor. Inorganic and organic compounds, such as nitrate and fumarate, are used as alternative electron acceptors in electron transfer pathway during anaerobic respiration; in anaerobic fermentation, energy is phosphorylated at the substrate-level, and electrons are transferred to the intermediate metabolite receptor molecule, rather than electron transfer phosphorylation to generate energy $[74,75]$. B. subtilis, a strict aerobe that has been proved to be a facultative anaerobe, can use nitrate as terminal electron acceptor for anaerobic respiration, and can also carry out mixed-acid/butanediol anaerobic fermentation in the presence of glucose, pyruvic acid, or amino acid [76]. The fermentation products include ethanol, acetic acid, lactic acid, and acetone [77].

\subsection{Anaerobic Regulatory Network of Bacillus subtilis}

A complete set of regulatory networks of Bacillus subtilis was stimulated by oxygen level change to make stress adjustments [78]. Gene expression related to anaerobic nitrate respiration and anaerobic pyruvate fermentation process is activated by the membranebound ResD-ResE two-component signal transduction system, the anaerobic regulator Fnr, which is activated by the changes in environmental oxygen levels, and the redoxsensing repressor Rex [79]. As shown in Figure 1, the sensor histidine kinase ResE is autophosphorylated when it senses the limitation of available oxygen, and then provides high-energy phosphate group to the homologous reaction regulator ResD, which makes ResD phosphorylation into ResD-P [80]. The expression of ldhlctP operon (encoding Llactate dehydrogenase and lactate permease), nasDEF gene (encoding the assimilatory nitrite reductase), hmp gene (coding for a flavohemoglobin), and ctaA gene (encoding a heme A sythase) are regulated by ResDE [81]. Meanwhile, the genes of nitrate respiration and anaerobic fermentation are induced by the total anaerobic regulator ResD-ResE. 


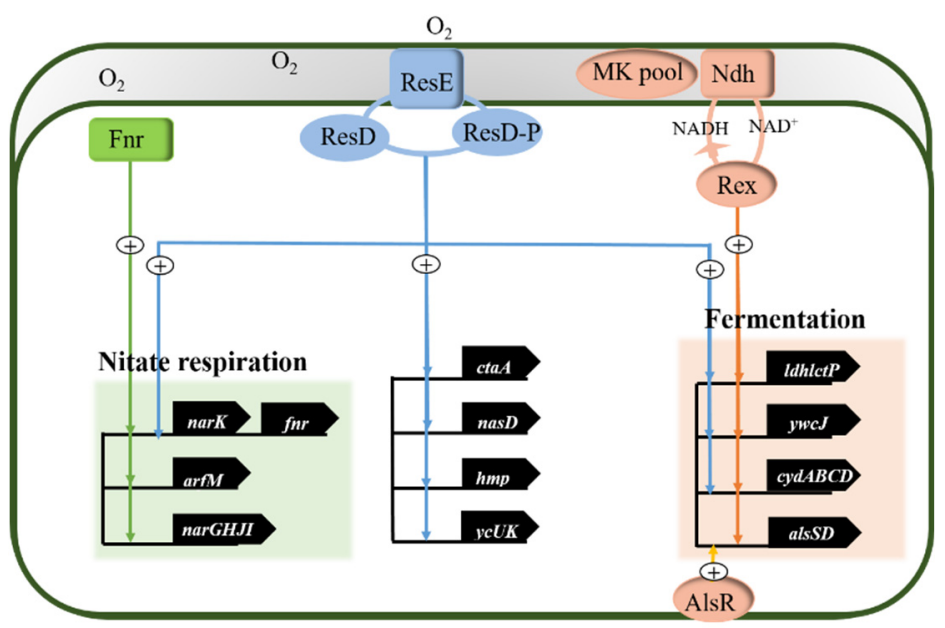

Figure 1. Anaerobic regulation network of Bacillus subtilis. Adapted from [81]. The green line represents that the Fnr regulator positively induces the nitrate respiration genes expression including narK gene, fnr gene, arfM gene, and narGHJI operon; The blue line represents that the ResD-ResE system positively regulate the expression of $l d h l c t P$ operon (encoding L-lactate dehydrogenase and lactate permease), nasDEF gene (encoding the assimilatory nitrite reductase), $h m p$ gene (coding for a flavohemoglobin), ctaA gene (encoding a heme A sythase), narK gene (encoding the nitrate reductase), fur gene (encoding the Fnr regulator), ywcJ gene (encoding a heme A sythase), and $c y d A B C D$ gene (encoding a heme A sythase); The orange line represents that the Rex regulator positively stimulates the fermentation genes expression, including ldhlctP operon, ywcJ gene, $c y d A B C D$ gene, and alsSD gene. The AlsR regulator positively induces the alsSD gene expression.

B. subtilis has encoded two distinct nitrate reductases, one for the assimilation of nitrate nitrogen and the other for nitrate respiration, both of which are induced by the anaerobic transcriptional regulator Fnr [82]. Fnr, a member of the catabolite gene activator protein (CAP) family of transcriptional regulators, induces the expression of nitrate respiration genes with absence of oxygen. The transcriptional units (the nitrate reductase encoded by narGHJI operon, nitrite transporters encoded by narK and fnr gene itself) directly activated by the anaerobic regulator (Fnr) under the oxygen limitation and the presence of nitrate. The arf $M$ gene, encoding anaerobic respiration and a fermentation regulator, also belongs to Fnr-bingding promoter of the regulon genes [83].

Rex, a redox-sensing repressor of $B$. subtilis, responds to the change of NADH/NAD ${ }^{+}$ ratio, which is related to the oxygen concentration within individual microenvironment. ResED activated the anaerobic transcription of ldhlctP, cydABCD, and $y w c J$ operons [84]. $\mathrm{NADH}$ binds with higher affinity to Rex than $\mathrm{NAD}^{+}$, inducing a domain rearrangement followed by the release of the repressor from the promoter. When the NADH/NAD ${ }^{+}$ratio increases, the rearranged Rex dimer is very inefficient to repress the expression of anaerobic fermentation genes. Recycling of NADH is accomplished by conversion of pyruvate to fermentation products $[85,86]$.

In the anaerobic fermentation of $B$. subtilis, two molecules of pyruvate are concentrated into acetolactate by acetolactate synthase (ALSS); Acetolactate is then converted to acetoacetate by the acetolactate decarboxylase ALSD (both enzymes are encoded by the alsSD operon) [87]. The production and secretion of acetoacetic acid is a mechanism for bacteria to maintain a constant $\mathrm{pH}$ value in individual microenvironment. The acidic medium of Bacillus licheniformis and Bacillus subtilis can induce the expression of alsSD operon, while the anaerobic and stationary phase expression of alsSD is alsR-controlled gene $[88,89]$. Acetic acid or acidic $\mathrm{pH}$ in the medium induced als $R$ gene to express transcription regulator AlsR, which shows significant homology to the LysR family of bacterial activator proteins [90]. The alsR gene is located in the upstream of alsSD operon, which effectively activates the transcription of alsSD operon, thus promoting acetoin synthesis in the mixed-acid/butanediol fermentation of B. subtil is [91,92]. 


\subsection{Anaerobic Energy Metabolism of Bacillus subtilis}

Bacteria switches between two kinds of energy generation in response to environmental changes: one is the generation of ATP at the substrate-level phosphorylation by chemical bond cleavage or oxidation, the other is the energy synthesized by the proton concentration gradient difference between inside and outside the cell, which is driven by the redox potential difference in the process of electron transfer $[93,94]$. In this process, oxygen and some inorganic salts (nitrate, $\mathrm{N}$-oxide, dimethyl sulfoxide (DMSO), fumarate, Fe (U), Mn (IV), sulfate, and many other compounds) served as external electron acceptors receive electrons and maintain the oxidation and reduction potential equilibrium in cells [81]. $\mathrm{NADH}+\mathrm{H}^{+}$and $\mathrm{NAD}^{+}$act as electron donor and electron acceptor in respiratory electron transfer chain to maintain intracellular potential balance, respectively. In the case of sufficient oxygen, $\mathrm{NADH}+\mathrm{H}^{+}$is oxidized to $\mathrm{NAD}^{+}$through tricarboxylic acid cycle. When oxygen is deficient, the ratio of $\mathrm{NADH}+\mathrm{H}^{+} / \mathrm{NAD}^{+}$is unbalanced, so bacteria have to choose other strategies such as nitrate respiration or pyruvate fermentation to complete the reoxidation of $\mathrm{NADH}+\mathrm{H}^{+}$[95]. The process of nitrate respiration and anaerobic fermentation is depicted in Figure 2.

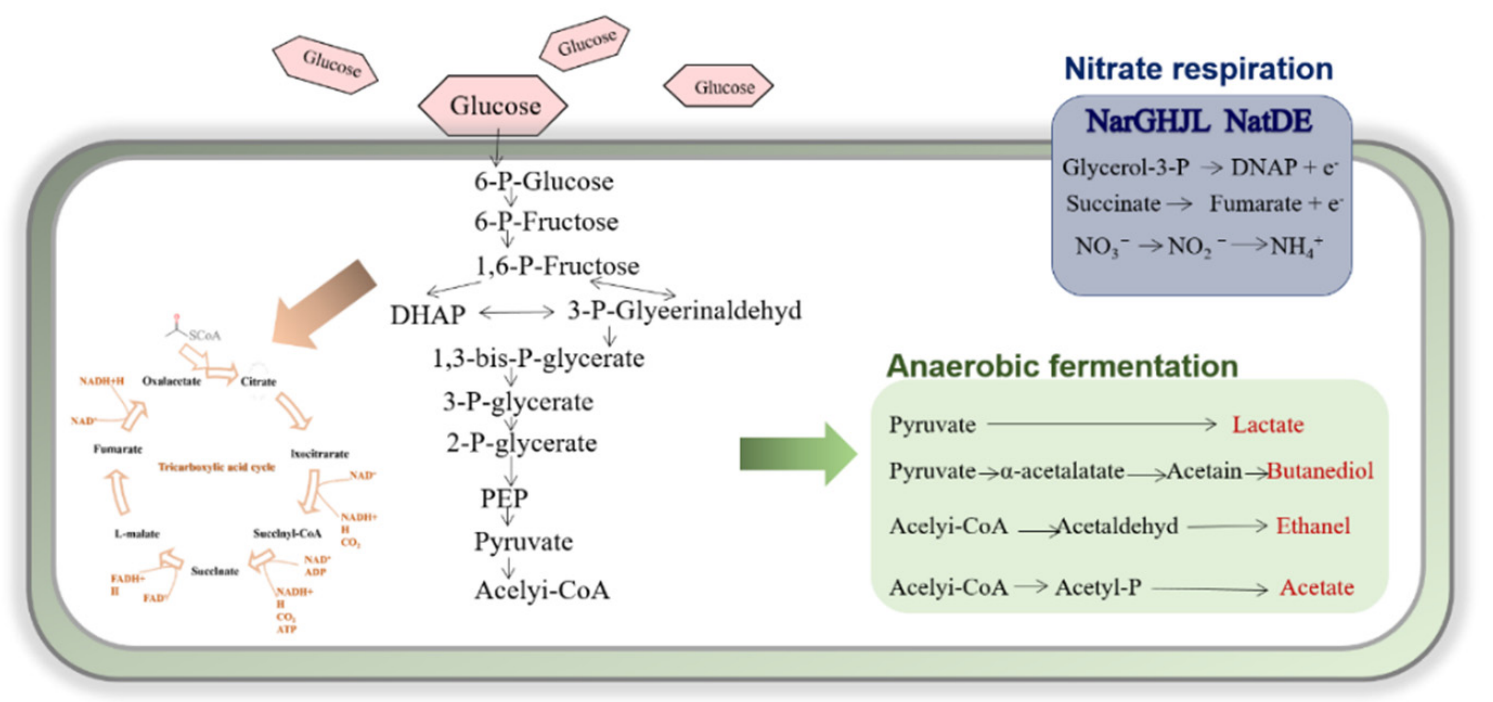

Figure 2. Glycolysis pathway and nitrate respiration pathway of Bacillus subtilis. Regulation of the anaerobic metabolism in Bacillus subtilis. Adapted from [81].

Unlike Escherichia coli and Bacillus licheniformis, the Bacillus subtilis does not grow anaerobically in glycerol succinate or fumarate medium because it lacks glycerol-3-dehydrogenase gene and fumarate reductase gene, and only has limited primary electron donor dehydrogenase, namely various forms of NDH-II and aerobic glycerol-3-phosphate dehydrogenase [96]. The nitrate reductase system of bacteria covered three types in E. coli: cytoplasmic assimilative $\mathrm{NAD}(\mathrm{P}) \mathrm{H}$-dependent nitrite reductases Nas, encoded by nas DE, membrane-bound respiratory nitrate reductases Nar, encoded by narGHJI, and the periplasmic dissimilatory nitrite/nitrate reductases Nap, encoded by the napFDAGHBC operon. These three kinds of proteins belong to the dimethyl sulfoxide reductase (DMSO) family and contain the bis-molybdopterin guanine dinucleotide (MGD) cofactor [97]. However, only two nitrate reductases function in nitrogen assimilation and in respiratory play a role in the process of nitrate respiration of B. subtilis [98]. In the electron transfer chain of nitrate respiration, two electrons flow through the heme $b$ of the cytochrome $b$ subunit (NarI) to the iron-sulfur clusters of the soluble subunit (NarH), and finally to the cytoplasmic subunit (NarG). NarG reduces nitrate to nitrite. Due to the different sites of quinol oxidation and nitrate reduction in the cytosol, nitrate reductase Nar contributes to the production of proton gradient. Nitrite is then further converted to ammonium by assimilatory nitrite reductase NasDE [99]. 
In the absence of external electron acceptors, pyruvate was transformed into lactic acid, acetone, 2,3-butanediol, ethanol, and acetic acid during anaerobic fermentation [49]. The most important thing in fermentation is the reoxidation of intracellular $\mathrm{NADH}+\mathrm{H}^{+}$. $\mathrm{NAD}^{+}$regeneration is mainly mediated by cytoplasmic lactate dehydrogenase (encoded by $l d h$ ) by converting pyruvate to lactate [100]. Acetate is produced from acetyl-CoA through two consecutive reactions catalyzed by phosphotransaminase and acetate kinase (encoded by pta and ackA operons), and ATP is generated in the process. Acetone can be converted to pyruvate, which is catalyzed by acetolactate synthase and acetolactate decarboxylase (encoded by alsSD), and then ethylene ketone is then reduced to 2,3-butanediol by 2,3-butanediol dehydrogenase (encoded by $b d h A$ ), with $\mathrm{NAD}^{+}$regeneration. During fermentation, ethanol is produced by acetyl-CoA, which first converts acetaldehyde to ethanol through acetaldehyde dehydrogenase [101].

\section{Non-Ribosomal Peptide Synthetases (NRPSs) of Surfactin}

Quorum Sensing (QS) is a type of population density-dependent cell-cell signaling that triggers changes in behavior when the population reaches a critical density. Quorum sensing systems rely on the production and sensing of extracellular signals [80]. In the gram-positive B. subtilis, the genetic competence (the ability to absorb foreign DNA from the environment), sporulation, the production of degrading enzymes and extracellular polysaccharides, and the synthesis of surfactin are all regulated by quorum sensing system [102]. This article describes the NRPSs mechanism of surfactin biosynthesis under aerobic conditions and the effect of correlation signal molecules on synthesis of surfactin in B. subtilis. In B. subtilis, surfactin is mainly synthesized by non-ribosomal peptide synthetases (NRPSs) which are exceptional megaenzymes that have evolved in bacteria and fungi to assemble highly complex, bioactive secondary metabolites of peptide origin $[103,104]$. To perform peptide complex chemical assembly, NRPSs rely on an array of large, repetitive catalytic units called modules, each comprised of several catalytic domains covalently linked within a single polypeptide chain [105]. At present, many factors affecting surfactin biosynthesis under aerobic conditions have been reported, but there are few reports about the factors influencing surfactin biosynthesis under anaerobic conditions.

\subsection{Regulator of Surfactin Synthesis in Bacillus subtilis}

The transcription and expression of surfactin synthesis $s r f A$ gene are regulated by a large number of regulatory factors, the most important is the two-component signal transduction system (TCS) in B. subtilis. Two-component signal transduction systems are a prototypical signaling cascade that are used by bacteria to couple changes in the extracellular environment to physiological effects $[105,106]$. Typically, TCS comprise a sensor histidine kinase $(\mathrm{HK})$, which consists of an input domain, detecting a signal, and a kinase domain, and a response regulator (RR). The sensor histidine kinase after the change of external environment is detected, the phosphorylation of the sensor's histidine kinase will transfer to the conserved aspartic residue on the $\mathrm{N}$-terminal receptor domain of the response regulator, resulting in the conformational change of the receptor, thus completing the signal transmission. B. subtilis 168 encodes for about 36 histidine kinases and 34 response regulators [107]. Here we will describe three TCS that are highly correlated with srfA operon transcription and expression: the ComAPQSX system, the DegS-DegU system, and the Rap-Phr system (Figure 3). 


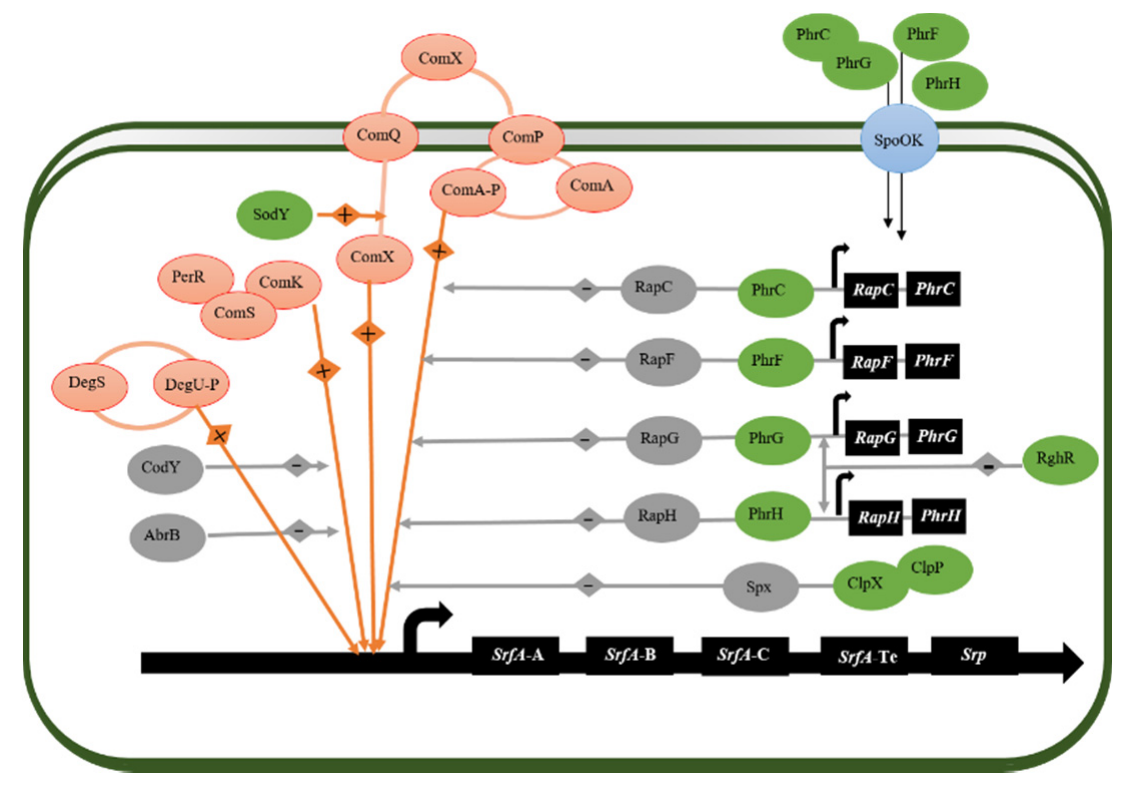

Figure 3. A gene regulatory model of surfacin biosynthesis. Orange indicates positive regulation and gray indicates negative regulation.

In the two-component signal transduction system of ComAPQSX, the modified extracellular peptide pheromone ComX interacts with the sensor histidine kinase ComP, which is autophosphorylated after stimulation and then transferred to the serine residue of ComA. Phosphorylated ComA binds to the ComA box upstream of $s r f A$ promoter (T/GCGG-N $4^{-}$ CCGCA) in the form of tetramer and initiates the transcription of $\operatorname{srfA}$ operon $[108,109]$. Secondly, the expression of $s r f A$ was repressed after hydrogen peroxide $\left(\mathrm{H}_{2} \mathrm{O}_{2}\right)$ treatment. PerR [110], a dimeric zinc protein with a regulatory site that coordinates either a $\mathrm{Fe}^{2+}$ or a $\mathrm{Mn}^{2+}$ metal ion, actively regulates the expression of $s r f A$ by binding to the PerR box in the upstream region of ComA box, and $\mathrm{H}_{2} \mathrm{O}_{2}$ inhibits the binding activity of PerR to DNA [111].

Another transcription factor, the DegS-DegU system, controls transcription of $s r f A$ genes in a manner depending on the level of the phosphorylated response regulator. The DegS-DegU system regulates many cellular processes, including exoprotease production, motility, biofilm formation, $\gamma$-polyglutamic acid production, and competence development in B. subtilis. The DegS autophosphorylates after sensing the signal of environmental changes, then the phosphoryl group is transferred to a conserved aspartic acid residue on the N-terminal receiver domain of the DegU. The phosphorylated DegU can effectively stimulate the transcription of $\operatorname{srf} A[105,112]$.

Eleven aspartate phosphatase proteins (RapA-RapK) are encoded by B. subtilis, among which RapC, RapF, RapG, RapH, and RapK are negative regulators of srfA transcription by inhibiting the binding of phosphorylated ComA-P to srfA promoter DNA [113]. Eight Phr peptides (PhrA, PhrC, PhrE, PhrF, PhrG, PhrH, PhrI, and PhrK) are encoded in B. subtilis. phr gene, which is located downstream of rap operon, and each Phr peptide inhibits the activity of Co-transcriptional Rap protein. Thus, it indirectly promotes the combination of ComA-P and srfA promoter, and plays a positive stimulating role [114]. RghR can inhibit the production of RapDGH protein by inhibiting the transcription of rapDGH operon, thus reducing the interference of RapDGH on ComA-P. and eventually promote the transcription of $\operatorname{srf} A$ operon [115].

By binding to the C-terminal domain of RNA polymerase (RNAP) subunit, Spx blocks the complex formation by preventing ComA-P and RNAP from binding to promoter, thus blocking $s r f A$ transcriptional activation. In addition, in high concentrations of amino acids such as Ile, Leu, and Val, Cody and AbrB inhibit the specific interaction between ComK and $\operatorname{srf} A$ promoter, resulting in the down-regulation of $\operatorname{srf} A$ transcription [116]. High 
levels of superoxide can specifically inhibit the transcription of comQXP operon, while superoxide dismutase SodA can reduce the interference of superoxide, thus promoting the transcriptional activation of comQXP operon and indirectly promoting the transcription of srfA operon [117]. Secondly, ATP-dependent proteolytic enzyme ClpXP effectively inhibits the binding of the C-terminal domain of RNA polymerase subunit (RNAP) by hydrolyzing RNA polymerase binding protein Spx, and indirectly promotes the formation of ComA-P complex with RNAP [118].

\subsection{Non-Ribosomal Peptide Sythetases (NRPSs)}

The biosynthesis of surfactin is based on non-ribosomal peptide synthetases (NRPSs) [119,120]. In non-ribosomal peptide synthetases (NRPSs) systems, multiple NRPSs subunits interact with each other in a specific linear order mediated by specific docking domains (DDs), to synthesize well-defined peptide products [121]. A simple extension module of NRPSs consists of at least three essential domains in the order of C-A-PCP: an adenylation (A) domain, which is responsible for the selection and activation of substrates to aminoacyl-adienoate. A small peptidyl carrier protein (PCP) domain that carries all acylintermediates on the terminal-SH group of its $4^{\prime}$-phosphopantetheine (Ppant) cofactor. A condensation $(\mathrm{C})$ domain that forms peptide bonds between the acyl-S-PCP intermediates of two adjacent modules [122]. In the process of surfactin biosynthesis, the termination module contains an additional thioesterase (TE) domain responsible for the release of the product by hydrolysis or cyclization to form cyclic or ring branched molecules [123]. In addition, other domains are responsible for the modification of the peptide rings, acetylation, glycosylation, and lipidization domains modify the polypeptide skeleton [124,125].

\section{Conclusions}

This review summarizes the thirty-six reported lipopeptide biosurfactants-producing strains and twenty-two other biosurfactants-producing stains, mostly isolated from oil reservoirs. The reported anaerobic biosurfactant-producing bacteria include thirty-seven strains of Bacillus, sixteen strains of Pseudomonas, one strain of Clostridium pasteurianum, two strains of Thermoanaerobacter, one Anaerophaga thermohalophila, one Geobacillus pallidus, one Rhodococcus ruber, one Tepidibacter mesophilus, one Luteimonas huabeiensis, one Enterobacter cloacae, and one Desulfovibrio desulfuricans. Nitrate is an alternative electron acceptor mainly for strains under oxygen-limiting conditions, including Desulfovibrio and Thermoanaerobacter, which select sulfate as an alternative electron acceptor. This shows that bacteria are able to produce biosurfactants under anaerobic conditions, although the anaerobic biosurfactant yield is much lower than that under aerobic conditions. The low anaerobic biosurfactant production in bacteria is contributed by the slow growth of bacteria in oxygen-limiting conditions. At the same time, the limited energy, producing in anaerobic conditions, is preferentially used in primary metabolic pathways rather than secondary metabolic pathways, which is also a major factor affecting the yield of biosurfactants. On the other hand, the difference of intercell microenvironments under oxygen-rich and oxygen-limited environments may affect the substrate selection due to the redox potential of the biochemical reactions and the usage of different electron acceptors. In general, the interaction of various factors leads to the low biosurfactants production of bacteria. Thus, understanding the factors affecting biosurfactant-production under microaerophilic and anaerobic conditions is important to the promising applications of bacteria in bioremediation, microbial enhanced oil recovery (MEOR), and the oxygenlimiting environments. Most of the research on microbial enhanced oil recovery (MEOR) by biosurfactant-producing bacteria under anaerobic conditions was in the laboratory stage, and the in-situ microbial flooding experiment on MEOR by anaerobic bacteria was still scarce. It is of great significance for the research and application of anaerobic biosurfactant production technology independent of gas injection to screen the bacteria resource of anaerobic biosurfactant production from the reservoir and analyze its biosurfactant production and metabolism process under the condition of oxygen deficiency. 
In general, during the utilization of any anaerobically produced biosurfactants bacteria for bioremediation or MEOR processes, the nature of used bacteria both from biosurfactants structure and the anaerobic growth and metabolic pathway must be examined first. Bacillus subtilis is most important of the anaerobic biosurfactant producer, the biosynthesis of surfactin is based on non-ribosomal peptide synthetases (encoded by $\operatorname{srfA}$ operon), which is regulated by quorum sensing system, a density-dependent signaling mechanism of microbial cells, and two-component signal transduction system (TCS), which is used to couple changes in the extracellular environment to physiological effects. Bacillus subtilis relies on a set of internal complex regulatory network to make adjustments and choose the appropriate generation energy and metabolic pathway to cope with environmental changes. It is proven that the facultative anaerobe Bacillus subtilis may use nitrate replace oxygen as terminal electron acceptor to transform energy and maintain the oxidation and reduction potential equilibrium in cell under oxygen-limiting conditions. The pyruvate fermentation is also an option in the absence of available electron acceptor and oxygen. The energy required by Bacillus subtilis to synthesize lipopeptide can be obtained by nitrate respiration or pyruvate fermentation in oxygen limited environments. However, how the synthesis process of surfactin will change and adjust when the environmental oxygen level changes, and the specific impact degree and transformation strategy of Bacillus subtilis, were unclear. Future research should intensify efforts in the difference of biosurfactants production of bacteria under the aerobic and anaerobic conditions. At the same time, the optimization of anaerobic biosurfactant production is also very effective for expanding the application range of anaerobic biosurfactant-producing bacteria.

Author Contributions: Conceptualization, S.-Z.Y. and B.-Z.M.; writing original draft preparation, J.-Y.L.; writing, review and editing, J.-Y.L., L.W., Y.-F.L., L.Z., H.-Z.G., J.-F.L., S.-Z.Y. and B.-Z.M. All authors have read and agreed to the published version of the manuscript.

Funding: This work was supported by the National Natural Science Foundation of China (4201101056, 41807324 and 52074129), the Shanghai International Collaboration Program (18230743300), the Fundamental Research Funds for the Central Universities of China (JKJ01211714), and the Research Program of the State Key Laboratory of Bioreactor Engineering.

Institutional Review Board Statement: Not applicable.

Informed Consent Statement: Not applicable.

Data Availability Statement: Not applicable.

Conflicts of Interest: The authors declare no conflict of interest.

\section{References}

1. Varjani, S.J.; Upasani, V.N. Critical Review on Biosurfactant Analysis, Purification and Characterization Using Rhamnolipid as a Model Biosurfactant. Bioresour. Technol. 2017, 232, 389-397.

2. Liu, J.F.; Mbadinga, S.M.; Yang, S.Z.; Gu, J.D.; Mu, B.Z. Chemical Structure, Property and Potential Applications of Biosurfactants Produced by Bacillus subtilis in Petroleum Recovery and Spill Mitigation. Int. J. Mol. Sci. 2015, 16, 4814-4837. [CrossRef] [PubMed]

3. Santos, V.S.V.; Silveira, E.; Pereira, B.B. Toxicity and Applications of Surfactin for Health and Environmental Biotechnology. J. Toxicol. Environ. Health B Crit. Rev. 2018, 21, 382-399. [CrossRef] [PubMed]

4. Zhao, Y.; Fan, T.; Chen, J.; Su, J.; Zhi, X.; Pan, P.; Zou, L.; Zhang, Q. Magnetic Bioinspired Micro/Nanostructured Composite Scaffold for Bone Regeneration. Colloids Surf. B Biointerfaces 2019, 174, 70-79. [CrossRef] [PubMed]

5. Ke, C.Y.; Lu, G.M.; Wei, Y.L.; Sun, W.J.; Hui, J.F.; Zheng, X.Y.; Zhang, Q.Z.; Zhang, X.L. Biodegradation of Crude Oil by Chelatococcus Daeguensis Hb-4 and Its Potential for Microbial Enhanced Oil Recovery (Meor) in Heavy Oil Reservoirs. Bioresour. Technol. 2019, 287, 121442. [CrossRef] [PubMed]

6. Kalogerakis, N.; Fava, F.; Corvini, P.F. Bioremediation Advances. N Biotechnol. 2017, 38, 41-42. [CrossRef] [PubMed]

7. Karas, J.A.; Carter, G.P.; Howden, B.P.; Turner, A.M.; Paulin, O.K.A.; Swarbrick, J.D.; Baker, M.A.; Li, J.; Velkov, T. StructureActivity Relationships of Daptomycin Lipopeptides. J. Med. Chem. 2020, 63, 13266-13290. [CrossRef]

8. Raaijmakers, J.M.; De Bruijn, I.; Nybroe, O.; Ongena, M. Natural Functions of Lipopeptides from Bacillus and Pseudomonas: More Than Surfactants and Antibiotics. FEMS Microbiol. Rev. 2010, 34, 1037-1062. [CrossRef] 
9. Vašíček, O.; Hájek, J.; Bláhová, L.; Hrouzek, P.; Babica, P.; Kubala, L.; Šindlerová, L. Cyanobacterial Lipopeptides Puwainaphycins and Minutissamides Induce Disruptive and Pro-Inflammatory Processes in Caco-2 Human Intestinal Barrier Model. Harmful Algae 2020, 96, 101849. [CrossRef]

10. Kozakai, R.; Ono, T.; Hoshino, S.; Takahashi, H.; Katsuyama, Y.; Sugai, Y.; Ozaki, T.; Teramoto, K.; Teramoto, K.; Tanaka, K.; et al. Acyltransferase That Catalyses the Condensation of Polyketide and Peptide Moieties of Goadvionin Hybrid Lipopeptides. Nat. Chem. 2020, 12, 869-877. [CrossRef]

11. Zhao, P.; Xue, Y.; Li, X.; Li, J.; Zhao, Z.; Quan, C.; Gao, W.; Zu, X.; Bai, X.; Feng, S. Fungi-Derived Lipopeptide Antibiotics Developed since 2000. Peptides 2019, 113, 52-65. [CrossRef] [PubMed]

12. Mnif, I.; Ghribi, D. Review Lipopeptides Biosurfactants: Mean Classes and New Insights for Industrial, Biomedical, and Environmental Applications. Biopolymers 2015, 104, 129-147. [CrossRef] [PubMed]

13. Walton, R.B.; Woodruff, H.B. A Crystalline Antifungal Agent, Mycosubtilin, Isolated from Subtilin Broth. J. Clin. Investig. 1949, 28, 924-926. [CrossRef]

14. Nishikiori, T.; Naganawa, H.; Muraoka, Y.; Aoyagi, T.; Umezawa, H. Plipastatins: New Inhibitors of Phospholipase A2, Produced by Bacillus Cereus Bmg302-Ff67. J. Antibiot. 1968, 39, 745-754. [CrossRef]

15. Fei, D.; Liu, F.F.; Gang, H.Z.; Liu, J.F.; Yang, S.Z.; Ye, R.Q.; Mu, B.Z. A New Member of the Surfactin Family Produced by Bacillus subtilis with Low Toxicity on Erythrocyte. Process. Biochem. 2020, 94, 164-171. [CrossRef]

16. Liu, X.Y.; Yang, S.Z.; Mu, B.Z. Isolation and Characterization of a C12-Lipopeptide Produced by Bacillus subtilis Hso 121. J. Pept. Sci. 2008, 14, 864-875. [CrossRef]

17. Li, Y.; Zou, A.H.; Ye, R.Q.; Mu, B.Z. Counterion-Induced Changes to the Micellization of Surfactin-C16 Aqueous Solution. J. Phys. Chem. B 2009, 113, 15272-15277. [CrossRef] [PubMed]

18. Liu, X.Y.; Yang, S.Z.; Mu, B.Z. Production and Characterization of a C15-Surfactin-O-Methyl Ester by a Lipopeptide Producing Strain Bacillus subtilis Hso121. Process. Biochem. 2009, 44, 1144-1151. [CrossRef]

19. Arima, K.; Kakinuma, A.; Tamura, G. Surfactin, a Crystalline Peptidelipid Surfactant Produced by Bacillus subtilis: Isolation, Characterization and Its Inhibition of Fibrin Clot Formation. Biochem. Biophys. Res. Commun. 1968, 31, 488-494. [CrossRef]

20. Zou, A.; Liu, J.; Garamus, V.M.; Zheng, K.; Willumeit, R.; Mu, B. Interaction between the Natural Lipopeptide [Glu1, Asp5)] Surfactin-C15 and Hemoglobin in Aqueous Solution. Biomacromolecules 2010, 11, 593-599. [CrossRef]

21. Mandal, S.M.; Sharma, S.; Pinnaka, A.K.; Kumari, A.; Korpole, S. Isolation and Characterization of Diverse Antimicrobial Lipopeptides Produced by Citrobacter and Enterobacter. BMC Microbiol. 2013, 13, 152. [CrossRef] [PubMed]

22. Veloo, A.C.M.; Tokman, H.B.; Jean-Pierre, H.; Dumont, Y.; Jeverica, S.; Lienhard, R.; Novak, A.; Rodloff, A.; Rotimi, V.; Wybo, I.; et al. Antimicrobial Susceptibility Profiles of Anaerobic Bacteria, Isolated from Human Clinical Specimens, within Different European and Surrounding Countries. A Joint Esgai Study. Anaerobe 2020, 61, 102111. [CrossRef] [PubMed]

23. Kivistö, A.T.; Karp, M.T. Halophilic Anaerobic Fermentative Bacteria. J. Biotechnol. 2011, 152, 114-124. [CrossRef]

24. Cooper, D.; Zajic, J.; Gerson, D.; Manninen, K. Isolation and Identification of Biosurfactants Produced During Anaerobic Growth of Clostridium pasteurianum. J. Ferment. Technol. 1980, 58, 83-86.

25. Ghojavand, H.; Vahabzadeh, F.; Azizmohseni, F. A Halotolerant, Thermotolerant, and Facultative Biosurfactant Producer: Identification and Molecular Characterization of a Bacterium and Evolution of Emulsifier Stability of a Lipopeptide Biosurfactant. Biotechnol. Bioprocess Eng. 2011, 16, 72-80. [CrossRef]

26. Xia, W.J.; Dong, H.P.; Yu, L. Oil-Degrading Characterization of Thermophilic and Halotolerant Strain Geobacillus Sp. Wj-2. J. Cent. South Univ. (Sci. Technol.) 2012, 43, 8-16.

27. Xia, W.J.; Yu, L.; Wang, P.; Xiu, J.L.; Dong, H.P. Characterization of a Thermophilic and Halotolerant Geobacillus Pallidus H9 and Its Application in Microbial Enhanced Oil Recovery (Meor). Ann. Microbiol. 2012, 62, 1779-1789.

28. Denger, K.; Schink, B. New Halo-and Thermotolerant Fermenting Bacteria Producing Surface-Active Compounds. Appl. Microbiol. Biotechnol. 1995, 44, 161-166. [CrossRef]

29. Zheng, C.; Yu, L.; Huang, L.; Xiu, J.; Huang, Z. Investigation of a Hydrocarbon-Degrading Strain, Rhodococcus Ruber Z25, for the Potential of Microbial Enhanced Oil Recovery. J. Pet. Sci. Eng. 2012, 81, 49-56. [CrossRef]

30. Tan, H.Q.; Wu, X.Y.; Zhang, X.Q.; Wu, M.; Zhu, X.F. Tepidibacter mesophilus Sp. Nov., a Mesophilic Fermentative Anaerobe Isolated from Soil Polluted by Crude Oil, and Emended Description of the Genus Tepidibacter. Int. J. Syst. Evol. Microbiol. 2012, 62, 66-70. [CrossRef]

31. Ke, C.Y.; Sun, W.J.; Li, Y.B.; Lu, G.M.; Zhang, Q.Z.; Zhang, X.L. Microbial Enhanced Oil Recovery in Baolige Oilfield Using an Indigenous Facultative Anaerobic Strain Luteimonas Huabeiensis Sp. Nov. J. Pet. Sci. Eng. 2018, 167, 160-167. [CrossRef]

32. La Riviere, J. The Production of Surface Active Compounds by Micro-Organisms and Its Possible Significance in Oil Recovery. Antonie Van Leeuwenhoek 1955, 21, 9-27. [CrossRef] [PubMed]

33. Javaheri, M.; Jenneman, G.E.; McInerney, M.J.; Knapp, R.M. Anaerobic Production of a Biosurfactant by Bacillus licheniformis Jf-2. Appl. Environ. Microbiol. 1985, 50, 698-700. [CrossRef] [PubMed]

34. Yakimov, M.M.; Timmis, K.N.; Wray, V.; Fredrickson, H.L. Characterization of a New Lipopeptide Surfactant Produced by Thermotolerant and Halotolerant Subsurface Bacillus licheniformis Bas50. Appl. Environ. Microbiol. 1995, 61, 1706-1713. [CrossRef] [PubMed]

35. Yakimov, M.M.; Amro, M.M.; Bock, M.; Boseker, K.; Fredrickson, H.L.; Kessel, D.G.; Timmis, K.N. The Potential of Bacillus licheniformis Strains for in Situ Enhanced Oil Recovery. J. Pet. Sci. Eng. 1997, 18, 147-160. [CrossRef] 
36. Kim, H.S.; Yoon, B.D.; Lee, C.H.; Suh, H.H.; Oh, H.M.; Katsuragi, T.; Tani, Y. Production and Properties of a Lipopeptide Biosurfactant from Bacillus subtilis C9. J. Ferment. Bioeng. 1997, 84, 41-46. [CrossRef]

37. Davis, D.; Lynch, H.; Varley, J. The Production of Surfactin in Batch Culture by Bacillus subtilis Atcc 21332 Is Strongly Influenced by the Conditions of Nitrogen Metabolism. Enzym. Microb. Technol. 1999, 25, 322-329. [CrossRef]

38. Grishchenkov, V.; Townsend, R.; McDonald, T.; Autenrieth, R.; Bonner, J.; Boronin, A. Degradation of Petroleum Hydrocarbons by Facultative Anaerobic Bacteria under Aerobic and Anaerobic Conditions. Process. Biochem. 2000, 35, 889-896. [CrossRef]

39. Pattnaik, P.; Kaushik, J.; Grover, S.; Batish, V. Purification and Characterization of a Bacteriocin-Like Compound (Lichenin) Produced Anaerobically by Bacillus licheniformis Isolated from Water Buffalo. J. Appl. Microbiol. 2001, 91, 636-645. [CrossRef]

40. Wei, Y.H.; Lai, C.C.; Chang, J.S. Using Taguchi Experimental Design Methods to Optimize Trace Element Composition for Enhanced Surfactin Production by Bacillus subtilis Atcc 21332. Process. Biochem. 2007, 42, 40-45. [CrossRef]

41. Youssef, N.; Simpson, D.; Duncan, K.; McInerney, M.; Folmsbee, M.; Fincher, T.; Knapp, R. In Situ Biosurfactant Production by Bacillus Strains Injected into a Limestone Petroleum Reservoir. Appl. Environ. Microbiol. 2007, 73, 1239-1247. [CrossRef]

42. Soudmand-asli, A.; Ayatollahi, S.S.; Mohabatkar, H.; Zareie, M.; Shariatpanahi, S.F. The in Situ Microbial Enhanced Oil Recovery in Fractured Porous Media. J. Pet. Sci. Eng. 2007, 58, 161-172. [CrossRef]

43. Guez, J.-S.; Müller, C.; Danze, P.; Büchs, J.; Jacques, P. Respiration Activity Monitoring System (Ramos), an Efficient Tool to Study the Influence of the Oxygen Transfer Rate on the Synthesis of Lipopeptide by Bacillus subtilis Atcc6633. J. Biotechnol. 2008, 134, 121-126. [CrossRef]

44. Gogotov, I.; Miroshnikov, A. The Influence of Growth Medium Composition and Physicochemical Factors on Biosurfactant Production by the Bacterium Bacillus licheniformis Vkm B-511. Appl. Biochem. Microbiol. 2009, 45, 588-592. [CrossRef]

45. Suthar, H.; Hingurao, K.; Desai, A.; Nerurkar, A. Selective Plugging Strategy-Based Microbial-Enhanced Oil Recovery Using Bacillus licheniformis Tt33. J. Microbiol. Biotechnol. 2009, 19, 1230-1237.

46. Senouci-Rezkallah, K.; Schmitt, P.; Jobin, M.P. Amino Acids Improve Acid Tolerance and Internal Ph Maintenance in Bacillus Cereus Atcc14579 Strain. Food Microbiol. 2011, 28, 364-372. [CrossRef] [PubMed]

47. Gudiña, E.J.; Pereira, J.F.; Rodrigues, L.R.; Coutinho, J.A.; Teixeira, J.A. Isolation and Study of Microorganisms from Oil Samples for Application in Microbial Enhanced Oil Recovery. Int. Biodeterior. Biodegrad. 2012, 68, 56-64.

48. Nihorimbere, V.; Cawoy, H.; Seyer, A.; Brunelle, A.; Thonart, P.; Ongena, M. Impact of Rhizosphere Factors on Cyclic Lipopeptide Signature from the Plant Beneficial Strain Bacillus Amyloliquefaciens S499. FEMS Microbiol. Ecol. 2012, 79, 176-191. [CrossRef] [PubMed]

49. Willenbacher, J.; Rau, J.T.; Rogalla, J.; Syldatk, C.; Hausmann, R. Foam-Free Production of Surfactin Via Anaerobic Fermentation of Bacillus subtilis Dsm 10(T). AMB Express 2015, 5, 21. [CrossRef] [PubMed]

50. Zhao, F.; Shi, R.; Cui, Q.; Han, S.; Dong, H.; Zhang, Y. Biosurfactant Production under Diverse Conditions by Two Kinds of Biosurfactant-Producing Bacteria for Microbial Enhanced Oil Recovery. J. Pet. Sci. Eng. 2017, 157, 124-130. [CrossRef]

51. Li, Z.; Lin, Z.; Qian, Q.; Feng, Y.; Wang, L.; Wang, W.; Li, X. Anaerobic Growth and Metabolism of a Bacillus Licheniformis for Oil Production. J. China Univ. Pet. (Nat. Sci. Ed.) 2018, 42, 179-184.

52. Lin, J.Z.; Feng, Y.; Tan, X.M.; Wang, J.; Wang, W.D.; Li, X.M. Study on Anaerobic Growth and Metabolism of a Strain of Bacillus Thermophilus for Oil Production. J. Xi'an Univ. Pet. 2019, 6, 115-119.

53. Domingues, P.M.; Almeida, A.; Serafim Leal, L.; Gomes, N.C.M.; Cunha, Â. Bacterial Production of Biosurfactants under Microaerobic and Anaerobic Conditions. Rev. Environ. Sci. Bio/Technol. 2017, 16, 239-272. [CrossRef]

54. Zhao, F.; Zhu, H.; Cui, Q.; Wang, B.; Su, H.; Zhang, Y. Anaerobic Production of Surfactin by a New Bacillus subtilis Isolate and the in Situ Emulsification and Viscosity Reduction Effect Towards Enhanced Oil Recovery Applications. J. Pet. Sci. Eng. 2021, 201, 108508. [CrossRef]

55. Yen, T.; Park, J.; Lee, K.; Li, Y. Fate of Surfactant Vesicles Surviving from Thermophilic, Halotolerant, Spore Forming, Clostridium thermohydrosulfuricum. Microb. Enhanc. Oil Recovery 1991, 31, 297-309.

56. Chayabutra, C.; Ju, L.K. Degradation of N-Hexadecane and Its Metabolites by Pseudomonas Aeruginosa under Microaerobic and Anaerobic Denitrifying Conditions. Appl. Environ. Microbiol. 2000, 66, 493-498. [CrossRef] [PubMed]

57. Chayabutra, C.; Wu, J.; Ju, L.K. Rhamnolipid Production by Pseudomonas Aeruginosa under Denitrification: Effects of Limiting Nutrients and Carbon Substrates. Biotechnol. Bioeng. 2001, 72, 25-33. [CrossRef]

58. Denger, K.; Warthmann, R.; Ludwig, W.; Schink, B. Anaerophaga Thermohalophila Gen. Nov., Sp. Nov., a Moderately Thermohalophilic, Strictly Anaerobic Fermentative Bacterium. Int. J. Syst. Evol. Microbiol. 2002, 52, 173-178. [CrossRef] [PubMed]

59. Vasileva-Tonkova, E.; Gesheva, V. Biosurfactant Production by Antarctic Facultative Anaerobe Pantoea Sp. During Growth on Hydrocarbons. Curr. Microbiol. 2007, 54, 136-141. [CrossRef] [PubMed]

60. Nozawa, T.; Tanikawa, T.; Hasegawa, H.; Takahashi, C.; Ando, Y.; Matsushita, M.; Nakagawa, Y.; Matsuyama, T. RhamnolipidDependent Spreading Growth of Pseudomonas aeruginosa on a High-Agar Medium: Marked Enhancement under Co2-Rich Anaerobic Conditions. Microbiol. Immunol. 2007, 51, 703-712. [CrossRef] [PubMed]

61. Hao, D.H.; Lin, J.Q.; Song, X.; Lin, J.Q.; Su, Y.J.; Qu, Y.B. Isolation, Identification, and Performance Studies of a Novel ParaffinDegrading Bacterium of Gordonia Amicalis Lh3. Biotechnol. Bioprocess Eng. 2008, 13, 61-68. [CrossRef]

62. Albino, J.D.; Nambi, I.M. Partial Characterization of Biosurfactant Produced under Anaerobic Conditions by Pseudomonas Sp Anbiosurf-1. Adv. Mater. Res. 2010, 93, 623-626. [CrossRef] 
63. Cortés, G.C.; Zapata PeAsco, I.; Carrillo, T.R.; Reyes Avila, J.; Mayol Castillo, M.; Vargas, S.R.; Lora, P.O. Evaluation of Indigenous Anaerobic Microorganisms from Mexican Carbonate Reservoirs with Potential Meor Application. J. Pet. Sci. Eng. 2012, 81, 86-93. [CrossRef]

64. Xia, W.J.; Luo, Z.B.; Dong, H.P.; Yu, L.; Cui, Q.F.; Bi, Y.Q. Synthesis, Characterization, and Oil Recovery Application of Biosurfactant Produced by Indigenous Pseudomonas Aeruginosa Wj-1 Using Waste Vegetable Oils. Appl. Biochem. Biotechnol. 2012, 166, 1148-1166. [CrossRef]

65. Pinzon, N.M.; Cook, A.G.; Ju, L.K. Continuous Rhamnolipid Production Using Denitrifying Pseudomonas Aeruginosa Cells in Hollow-Fiber Bioreactor. Biotechnol. Prog. 2013, 29, 352-358. [CrossRef]

66. Sarafzadeh, P.; Hezave, A.Z.; Ravanbakhsh, M.; Niazi, A.; Ayatollahi, S. Enterobacter Cloacae as Biosurfactant Producing Bacterium: Differentiating Its Effects on Interfacial Tension and Wettability Alteration Mechanisms for Oil Recovery During Meor Process. Colloids Surf. B Biointerfaces 2013, 105, 223-229. [CrossRef]

67. Zargari, S.; Ramezani, A.; Ostvar, S.; Rezaei, R.; Niazi, A.; Ayatollahi, S. Isolation and Characterization of Gram-Positive Biosurfactant-Producing Halothermophilic Bacilli from Iranian Petroleum Reservoirs. Jundishapur J. Microbiol. 2014, 7, 1098110991. [CrossRef]

68. Zhao, F.; Mandlaa, M.; Hao, J.; Liang, X.; Shi, R.; Han, S.; Zhang, Y. Optimization of Culture Medium for Anaerobic Production of Rhamnolipid by Recombinant Pseudomonas Stutzeri Rhl for Microbial Enhanced Oil Recovery. Lett. Appl. Microbiol. 2014, 59, 231-237. [CrossRef]

69. Zhao, F.; Cui, Q.; Han, S.; Dong, H.; Zhang, J.; Ma, F.; Zhang, Y. Enhanced Rhamnolipid Production of Pseudomonas Aeruginosa Sg by Increasing Copy Number of Rhlab Genes with Modified Promoter. RSC Adv. 2015, 5, 70546-70552. [CrossRef]

70. Zhao, F.; Ma, F.; Shi, R.; Zhang, J.; Han, S.; Zhang, Y. Production of Rhamnolipids by Pseudomonas Aeruginosa Is Inhibited by H2s but Resumes in a Co-Culture with P. Stutzeri: Applications for Microbial Enhanced Oil Recovery. Biotechnol. Lett. 2015, 37, 1803-1808. [CrossRef] [PubMed]

71. Zhao, F.; Li, P.; Guo, C.; Shi, R.J.; Zhang, Y. Bioaugmentation of Oil Reservoir Indigenous Pseudomonas Aeruginosa to Enhance Oil Recovery through in-Situ Biosurfactant Production without Air Injection. Bioresour. Technol. 2018, 251, 295-302. [CrossRef]

72. Fan, Y.; Wang, J.; Gao, C.; Zhang, Y.; Du, W. A Novel Exopolysaccharide-Producing and Long-Chain N-Alkane Degrading Bacterium Bacillus licheniformis Strain Dm-1 with Potential Application for in-Situ Enhanced Oil Recovery. Sci. Rep. 2020, 10, 8519. [CrossRef] [PubMed]

73. Riemenschneider, C.; Zerr, W.; Vater, N.; Brunn, H.; Mohring, S.A.I.; Hamscher, G. Analysis and Behavior of Colistin During Anaerobic Fermentation. Bioresour. Technol. 2014, 170, 303-309. [CrossRef] [PubMed]

74. Bulot, S.; Audebert, S.; Pieulle, L.; Seduk, F.; Baudelet, E.; Espinosa, L.; Pizay, M.C.; Camoin, L.; Magalon, A. Clustering as a Means to Control Nitrate Respiration Efficiency and Toxicity in Escherichia coli. mBio 2019, 10, e01832-01819. [CrossRef] [PubMed]

75. Carlson, H.K.; Lui, L.M.; Price, M.N.; Kazakov, A.E.; Carr, A.V.; Kuehl, J.V.; Owens, T.K.; Nielsen, T.; Arkin, A.P.; Deutschbauer, A.M. Selective Carbon Sources Influence the End Products of Microbial Nitrate Respiration. ISME 2020, 14, 2034-2045. [CrossRef] [PubMed]

76. Nakano, M.M.; Dailly, Y.P.; Zuber, P.; Clark, D.P. Characterization of Anaerobic Fermentative Growth of Bacillus subtilis: Identification of Fermentation End Products and Genes Required for Growth. J. Bacteriol. 1997, 179, 6749-6755. [CrossRef]

77. Clements, L.D.; Streips, U.N.; Miller, B.S. Differential Proteomic Analysis of Bacillus subtilis Nitrate Respiration and Fermentation in Defined Medium. Proteomics 2002, 2, 1724-1734. [CrossRef]

78. Nakano, M.M.; Zuber, P. Anaerobic Growth of a "Strict Aerobe" (Bacillus subtilis). Annu. Rev. Microbiol. 1998, 52, 165-190. [CrossRef]

79. Geng, H.; Zhu, Y.; Mullen, K.; Zuber, C.S.; Nakano, M.M. Characterization of Resde-Dependent Fnr Transcription in Bacillus subtilis. J. Bacteriol. 2007, 189, 1745-1755. [CrossRef]

80. Whiteley, M.; Diggle, S.P.; Greenberg, E.P. Progress in and Promise of Bacterial Quorum Sensing Research. Nature 2017, 551, 313-320. [CrossRef]

81. Härtig, E.; Jahn, D. Regulation of the Anaerobic Metabolism in Bacillus subtilis. Adv. Microb. Physiol. 2012, 61, 195-216. [PubMed]

82. Ogawa, K.; Akagawa, E.; Yamane, K.; Sun, Z.W.; LaCelle, M.; Zuber, P.; Nakano, M.M. The Nasb Operon and Nasa Gene Are Required for Nitrate/Nitrite Assimilation in Bacillus subtilis. J. Bacteriol. 1995, 177, 1409-1413. [CrossRef] [PubMed]

83. Marino, M.; Ramos, H.C.; Hoffmann, T.; Glaser, P.; Jahn, D. Modulation of Anaerobic Energy Metabolism of Bacillus subtilis by Arfm (Ywid). J. Bacteriol. 2001, 183, 6815-6821. [CrossRef] [PubMed]

84. Puri-Taneja, A.; Schau, M.; Chen, Y.; Hulett, F.M. Regulators of the Bacillus subtilis Cydabcd Operon: Identification of a Negative Regulator, Ccpa, and a Positive Regulator, Resd. J. Bacteriol. 2007, 189, 3348-3358. [CrossRef] [PubMed]

85. Gyan, S.; Shiohira, Y.; Sato, I.; Takeuchi, M.; Sato, T. Regulatory Loop between Redox Sensing of the Nadh/Nad $\left(^{+}\right)$ Ratio by Rex (Ydih) and Oxidation of Nadh by Nadh Dehydrogenase Ndh in Bacillus subtilis. J. Bacteriol. 2006, 188, 7062-7071. [CrossRef] [PubMed]

86. Laouami, S.; Clair, G.; Armengaud, J.; Duport, C. Proteomic Evidences for Rex Regulation of Metabolism in Toxin-Producing Bacillus Cereus Atcc 14579. PLoS ONE 2014, 9, 107354-107363. [CrossRef]

87. Sommer, B.; von Moeller, H.; Haack, M.; Qoura, F.; Langner, C.; Bourenkov, G.; Garbe, D.; Loll, B.; Brück, T. Detailed StructureFunction Correlations of Bacillus subtilis Acetolactate Synthase. Chembiochem 2015, 16, 110-118. [CrossRef]

88. Atsumi, S.; Li, Z.; Liao, J.C. Acetolactate Synthase from Bacillus subtilis Serves as a 2-Ketoisovalerate Decarboxylase for Isobutanol Biosynthesis in Escherichia coli. Appl. Environ. Microbiol. 2009, 75, 6306-6311. [CrossRef] 
89. Huo, Y.; Zhan, Y.; Wang, Q.; Li, S.; Yang, S.; Nomura, C.T.; Wang, C.; Chen, S. Acetolactate Synthase (Alss) in Bacillus licheniformis Wx-02: Enzymatic Properties and Efficient Functions for Acetoin/Butanediol and L-Valine Biosynthesis. Bioprocess Biosyst. Eng. 2018, 41, 87-96. [CrossRef]

90. Skjoedt, M.L.; Snoek, T.; Kildegaard, K.R.; Arsovska, D.; Eichenberger, M.; Goedecke, T.J.; Rajkumar, A.S.; Zhang, J.; Kristensen, M.; Lehka, B.J.; et al. Engineering Prokaryotic Transcriptional Activators as Metabolite Biosensors in Yeast. Nat. Chem. Biol. 2016, 12, 951-958. [CrossRef]

91. Fu, Y.; Cai, Q.; Wang, Y.; Li, W.; Yu, J.; Yang, G.; Lin, W.; Lin, X. Four Lysr-Type Transcriptional Regulator Family Proteins (Lttrs) Involved in Antibiotic Resistance in Aeromonas hydrophila. World J. Microbiol. Biotechnol. 2019, 35, 127. [CrossRef]

92. Wang, E.; Bauer, M.C.; Rogstam, A.; Linse, S.; Logan, D.T.; von Wachenfeldt, C. Structure and Functional Properties of the Bacillus subtilis Transcriptional Repressor Rex. Mol. Microbiol. 2008, 69, 466-478. [CrossRef]

93. Abbasian, B.; Shair, A.; O'Gorman, D.B.; Pena-Diaz, A.M.; Brennan, L.; Engelbrecht, K.; Koenig, D.W.; Reid, G.; Burton, J.P. Potential Role of Extracellular Atp Released by Bacteria in Bladder Infection and Contractility. mSphere 2019, 4, e00439-00419. [CrossRef]

94. Kühlbrandt, W. Structure and Mechanisms of F-Type Atp Synthases. Annu. Rev. Biochem. 2019, 88, 515-549. [CrossRef]

95. Joicy, A.; Song, Y.C.; Yu, H.; Chae, K.J. Nitrite and Nitrate as Electron Acceptors for Bioelectrochemical Ammonium Oxidation under Electrostatic Field. J. Environ. Manag. 2019, 250, 109517. [CrossRef] [PubMed]

96. Clements, L.D.; Miller, B.S.; Streips, U.N. Comparative Growth Analysis of the Facultative Anaerobes Bacillus subtilis, Bacillus licheniformis, and Escherichia coli. Syst. Appl. Microbiol. 2002, 25, 284-286. [CrossRef] [PubMed]

97. Zhao, G.; Zhao, Y.; Lou, W.; Su, J.; Wei, S.; Yang, X.; Wang, R.; Guan, R.; Pu, H.; Shen, W. Nitrate Reductase-Dependent Nitric Oxide Is Crucial for Multi-Walled Carbon Nanotube-Induced Plant Tolerance against Salinity. Nanoscale 2019, 11, 10511-10523. [CrossRef] [PubMed]

98. Torres, M.J.; Avila, S.; Bedmar, E.J.; Delgado, M.J. Overexpression of the Periplasmic Nitrate Reductase Supports Anaerobic Growth by Ensifer meliloti. FEMS Microbiol. Lett. 2018, 365, fny041. [CrossRef]

99. Chamizo-Ampudia, A.; Sanz-Luque, E.; Llamas, A.; Galvan, A.; Fernandez, E. Nitrate Reductase Regulates Plant Nitric Oxide Homeostasis. Trends Plant Sci. 2017, 22, 163-174. [CrossRef]

100. Stock, D.W.; Quattro, J.M.; Whitt, G.S.; Powers, D.A. Lactate Dehydrogenase (Ldh) Gene Duplication During Chordate Evolution: The Cdna Sequence of the Ldh of the Tunicate Styela Plicata. Mol. Biol. Evol. 1997, 14, 1273-1284. [CrossRef]

101. Zheng, T.; Olson, D.G.; Murphy, S.J.; Shao, X.; Tian, L.; Lynd, L.R. Both Adhe and a Separate Nadph-Dependent Alcohol Dehydrogenase Gene, Adha, Are Necessary for High Ethanol Production in Thermoanaerobacterium saccharolyticum. J. Bacteriol. 2017, 199, e00542-00516. [CrossRef]

102. Bareia, T.; Pollak, S.; Eldar, A. Self-Sensing in Bacillus subtilis Quorum-Sensing Systems. Nat. Microbiol. 2018, 3, 83-89. [CrossRef]

103. Reimer, J.M.; Eivaskhani, M.; Harb, I.; Guarné, A.; Weigt, M.; Schmeing, T.M. Structures of a Dimodular Nonribosomal Peptide Synthetase Reveal Conformational Flexibility. Science 2019, 366, 706-711. [CrossRef]

104. Boraker, D.K. Degu Colony Available. Science 1976, 192, 322. [CrossRef] [PubMed]

105. Cairns, L.S.; Martyn, J.E.; Bromley, K.; Stanley-Wall, N.R. An Alternate Route to Phosphorylating Degu of Bacillus subtilis Using Acetyl Phosphate. BMC Microbiol. 2015, 15, 78-90. [CrossRef] [PubMed]

106. Zschiedrich, C.P.; Keidel, V.; Szurmant, H. Molecular Mechanisms of Two-Component Signal Transduction. J. Mol. Biol. 2016, 428, 3752-3775. [CrossRef]

107. Liu, C.; Sun, D.; Zhu, J.; Liu, W. Two-Component Signal Transduction Systems: A Major Strategy for Connecting Input Stimuli to Biofilm Formation. Front. Microbiol. 2018, 9, 3279. [CrossRef] [PubMed]

108. Bacon Schneider, K.; Palmer, T.M.; Grossman, A.D. Characterization of Comq and Comx, Two Genes Required for Production of Comx Pheromone in Bacillus subtilis. J. Bacteriol. 2002, 184, 410-419. [CrossRef] [PubMed]

109. Luo, P.; Morrison, D.A. Transient Association of an Alternative Sigma Factor, Comx, with Rna Polymerase During the Period of Competence for Genetic Transformation in Streptococcus pneumoniae. J. Bacteriol. 2003, 185, 349-358. [CrossRef] [PubMed]

110. Duarte, V.; Latour, J.M. Perr Vs Ohrr: Selective Peroxide Sensing in Bacillus subtilis. Mol Biosyst 2010, 6, 316-323. [CrossRef]

111. Aspiras, M.B.; Ellen, R.P.; Cvitkovitch, D.G. Comx Activity of Streptococcus Mutans Growing in Biofilms. FEMS Microbiol. Lett. 2004, 238, 167-174.

112. Gupta, M.; Rao, K.K. Epr Plays a Key Role in Degu-Mediated Swarming Motility of Bacillus subtilis. FEMS Microbiol. Lett. 2009, 295, 187-194. [CrossRef]

113. O'Loughlin, C.T.; Miller, L.C.; Siryaporn, A.; Drescher, K.; Semmelhack, M.F.; Bassler, B.L. A Quorum-Sensing Inhibitor Blocks Pseudomonas Aeruginosa Virulence and Biofilm Formation. Proc. Natl. Acad. Sci. USA 2013, 110, 17981-17986. [CrossRef]

114. Gallego del Sol, F.; Marina, A. Structural Basis of Rap Phosphatase Inhibition by Phr Peptides. PLoS Biol. 2013, 11 , e1001511. [CrossRef] [PubMed]

115. Defoirdt, T. Quorum-Sensing Systems as Targets for Antivirulence Therapy. Trends Microbiol. 2018, 26, 313-328. [CrossRef] [PubMed]

116. Duitman, E.H.; Wyczawski, D.; Boven, L.G.; Venema, G.; Kuipers, O.P.; Hamoen, L.W. Novel Methods for Genetic Transformation of Natural Bacillus subtilis Isolates Used to Study the Regulation of the Mycosubtilin and Surfactin Synthetases. Appl. Environ. Microbiol. 2007, 73, 3490-3496. [CrossRef] [PubMed] 
117. Haque, S.; Yadav, D.K.; Bisht, S.C.; Yadav, N.; Singh, V.; Dubey, K.K.; Jawed, A.; Wahid, M.; Dar, S.A. Quorum Sensing Pathways in Gram-Positive and -Negative Bacteria: Potential of Their Interruption in Abating Drug Resistance. J. Chemother. 2019, 31, 161-187. [CrossRef]

118. Silpe, J.E.; Bassler, B.L. A Host-Produced Quorum-Sensing Autoinducer Controls a Phage Lysis-Lysogeny Decision. Cell 2019, 176, 268-280. [CrossRef]

119. Lee, T.V.; Johnson, R.D.; Arcus, V.L.; Lott, J.S. Prediction of the Substrate for Nonribosomal Peptide Synthetase (Nrps) Adenylation Domains by Virtual Screening. Proteins 2015, 83, 2052-2066. [CrossRef] [PubMed]

120. Hacker, C.; Cai, X.; Kegler, C.; Zhao, L.; Weickhmann, A.K.; Wurm, J.P.; Bode, H.B.; Wöhnert, J. Structure-Based Redesign of Docking Domain Interactions Modulates the Product Spectrum of a Rhabdopeptide-Synthesizing Nrps. Nat. Commun. 2018, 9 , 4366. [CrossRef]

121. Sussmuth, R.D.; Mainz, A. Nonribosomal Peptide Synthesis-Principles and Prospects. Angew. Chem. Int. Ed. Engl. 2017, 56, 3770-3821. [CrossRef] [PubMed]

122. Berry, D.; Mace, W.; Grage, K.; Wesche, F.; Gore, S.; Schardl, C.L.; Young, C.A.; Dijkwel, P.P.; Leuchtmann, A.; Bode, H.B.; et al. Efficient Nonenzymatic Cyclization and Domain Shuffling Drive Pyrrolopyrazine Diversity from Truncated Variants of a Fungal Nrps. Proc. Natl. Acad. Sci. USA 2019, 116, 25614-25623. [CrossRef]

123. Gao, L.; Liu, H.; Ma, Z.; Han, J.; Lu, Z.; Dai, C.; Lv, F.; Bie, X. Translocation of the Thioesterase Domain for the Redesign of Plipastatin Synthetase. Sci. Rep. 2016, 6, 38467. [CrossRef]

124. Drake, E.J.; Miller, B.R.; Shi, C.; Tarrasch, J.T.; Sundlov, J.A.; Allen, C.L.; Skiniotis, G.; Aldrich, C.C.; Gulick, A.M. Structures of Two Distinct Conformations of Holo-Non-Ribosomal Peptide Synthetases. Nature 2016, 529, 235-238. [CrossRef]

125. Marahiel, M.A. A Structural Model for Multimodular Nrps Assembly Lines. Nat. Prod. Rep. 2016, 33, 136-140. [CrossRef] 